\title{
Total Synthesis and in Vivo Quantitation of Phytofurans Derived from $\alpha$-Linolenic Acid
}

\author{
Claire Cuyamendous, ${ }^{[\mathrm{a}]}$ Kin Sum Leung, ${ }^{[\mathrm{b}]}$ Valérie Bultel-Poncé, ${ }^{[\mathrm{a}]}$ Alexandre Guy, ${ }^{[\mathrm{a}]}$ \\ Thierry Durand, ${ }^{[a]}$ Jean-Marie Galano, ${ }^{*[a]}$ Jetty Chung-Yung Lee, ${ }^{*[b]}$ and Camille Oger*[a]
}

Abstract: Phytoprostanes (PhytoPs) are produced in plants and seeds by non-enzymatic free-radical pathways from $\alpha$-linolenic acid (ALA). We recently highlighted the formation of a new class of compounds from ALA, namely phytofurans (PhytoFs). In biological samples, these compounds are produced as mixtures, and their analytical exploration remains challenging without their pure synthetic forms. The synthesis of some phytofurans is described here. The use of an enantiomerically enriched intermediate allowed for the first time access to both families of PhytoFs, the alkenyl and enediol classes. For the first time, PhytoF metabolites have been quantitated in the liver tissue of rats treated with an ALA-rich flaxseed or flaxseed oil diet.

\section{Introduction}

Oxidative stress is responsible for the oxidation of phospholipid moieties in living organisms. Under these conditions, arachidonic acid (AA; C20:4 n-6), adrenic acid ( $A d A ; C 22: 4 n-6)$, and docosahexaenoic acid (DHA; $C 22: 6 n-3)$ are oxidized and metabolized through non-enzymatic free-radical pathways to form isoprostanes (IsoPs), ${ }^{[1]}$ dihomo-isoprostanes (Dihomo-IsoPs), ${ }^{[2]}$ and neuroprostanes (NeuroPs), ${ }^{[3]}$ respectively. In addition to being biomarkers for oxidative stress in human diseases, isoprostanoids have various biological activities involving vasoconstriction, pulmonary inflammation, and neurovascular abnormalities, ${ }^{[4]}$ and they also have anti-arrhythmic properties. ${ }^{[5]}$ The major polyunsaturated fatty acid (PUFA) in plants is $\alpha$-linolenic acid (ALA; C18:3 n-3), which can release phytoprostanes (PhytoPs) through a free-radical process, ${ }^{[6]}$ PhytiPS that can mediate plant defense mechanisms ${ }^{[7]}$ and neuroprotection in human cells. ${ }^{[8]}$

In a similar manner, the biosynthesis of 2,3,5-trisubstituted tetrahydrofuran structures, named isofurans (IsoFs) ${ }^{[9]}$ from $A A$, dihomo-isofurans (dihomo-IsoFs) ${ }^{[10]}$ from $\mathrm{AdA}$, and neurofurans (NeuroFs) ${ }^{[11]}$ from DHA, has been discovered. We recently investigated the presence of such a mechanistic process in plants, and we highlighted, for the first time, the existence of natural tetrahydrofuranic oxygenated products of ALA, the phytofurans

[a] Institut des Biomolécules Max Mousseron (IBMM), UMR CNRS 5247, Université de Montpellier, ENSCM, Faculté de Pharmacie, 15 Av. Charles Flahault, BP 14491, 34093 Montpellier CEDEX 05, France E-mail: jean-marie.galano@umontpellier.fr camille.oger@umontpellier.fr https://ibmm.umontpellier.fr/

[b] School of Biological Sciences, The University of Hong Kong Pokfulam Road, Hong Kong SAR, China

E-mail: jettylee@hku.hk www.biosch.hku.hk

Supporting information and $O R C I D(s)$ from the author(s) for this article are
(PhytoFs). ${ }^{[12]}$ These new molecules were quantified in some nuts (pine and walnut) and seeds (chia and flax) by LC-MS/MS.

Similarly to IsoFs, dihomo-IsoFs, and NeuroFs, two biosynthetic pathways for PhytoFs coexist. These lead to two classes of PhytoFs, specifically alkenyl and enediol compounds, making a total of 128 potential phytofuran isomers.

To date, four main synthetic strategies for these furanoids have been reported in the literature. ${ }^{[13]}$ In 2004, Taber et al. reported the first total synthesis of alkenyl-type IsoFs (8-epi-SC$\Delta^{13}$-9-IsoF and 8,15-diepi-SC- $\Delta^{13}-9-$ IsoF $)^{[14]}$ through a diol epoxide benzenesulfonate cyclization. ${ }^{[15]}$ After some modification of this strategy, the synthesis of enediol-type compounds (15-epient-SC- $\Delta^{13}-8$-IsoF and ent-SC- $\Delta^{13}-8$-IsoF) was possible. ${ }^{[16]}$ The first synthesis of a NeuroF compound (7-epi-ST- $\Delta^{8}-10-$ NeuroF), using a Trost asymmetric alkylation, was described by Zanoni et al..17] In 2014, our group developed a strategy based on 5-exo-tet and 5-endo-tet cyclization reactions directed by a Borhan orthoester to successfully synthesize alkenyl dihomoIsoF 10-epi-17(RS)-SC- $\Delta^{15}$-11-dihomo-IsoF, and enediol dihomoIsoF and NeuroF 7(RS)-ST- $\Delta^{8}$-11-dihomo-IsoF and 4(RS)-ST- $\Delta^{5}-8$ NeuroF. ${ }^{[10,18]}$ We then recently achieved the first total synthesis of enediol PhytoF ent-16(RS)-13-epi-ST- $\Delta^{14}$-9-PhytoF (1) through a one-pot Payne rearrangement/epoxide opening/5-exo-tet cyclization (Scheme 1). ${ }^{[12]}$ To highlight the divergence and flexibility of this strategy, we describe in this paper new total syntheses of one other enediol PhytoF, ent-9(RS)-12-epi-ST- $\Delta^{10}-13-$ PhytoF (2), and one alkenyl-type compound, ent-16(RS)-9-epiST- $\Delta^{14}$-10-PhytoF (3).

In order to understand the metabolism of PhytoFs, we supplemented the diet of rodents $(n=6)$ with ALA-rich flaxseed (FS) or flaxseed oil (FSO) for 28 days. ${ }^{[19]}$ The concentrations of ALA in the FSO and FS diets were consistent (1\% per gram of diet). The liver tissues were then analyzed for PhytoFs, including the newly synthesized ent-9(RS)-12-epi-ST- $\Delta^{14}-13-$ PhytoF (2) and ent-16(RS)-9-epi-ST- $\Delta^{14}-10-$ PhytoF (3), using LC-MS/MS. ${ }^{[12]}$ 


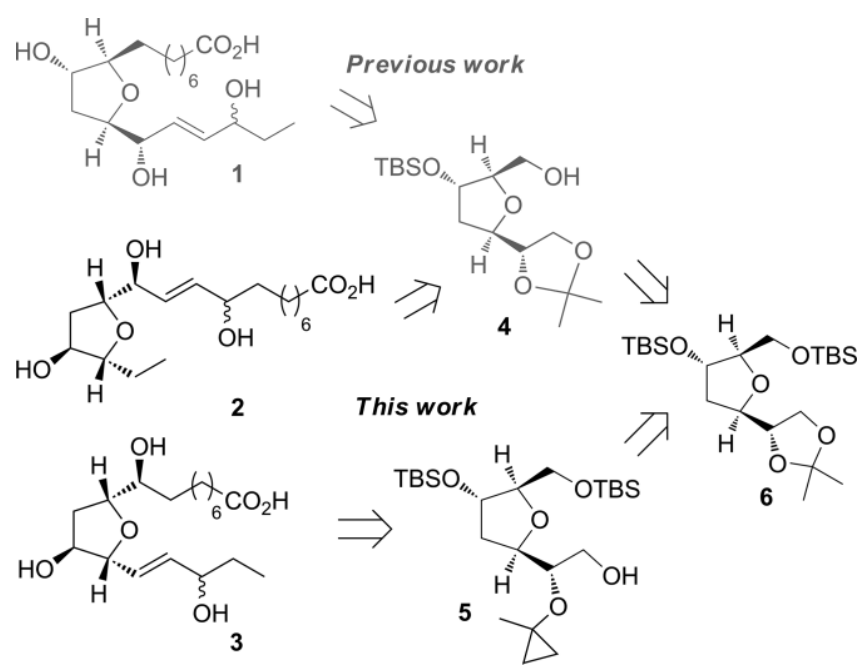

Scheme 1. Retrosynthetic analysis of enediol and alkenyl PhytoFs 1, 2, and $\mathbf{3}$.

The liver was selected as it is the main organ for the synthesis, metabolism, and storage of fats and lipids.

\section{Results and Discussion}

\section{Synthesis of Phytofurans}

The synthesis of enediol PhytoF 2 started from common monoprotected TBS (tert-butyldimethylsilyl) ether intermediate $\mathbf{4}$ as a 4:1 mixture of diastereoisomers. ${ }^{[12]}$ The synthesis of this intermediate involved an unprecedented Payne rearrangement of $C_{2}$-symmetric ( $2 S, 2^{\prime} S, 3 S, 3^{\prime} S$ )-bis(epoxide) 7 , followed by a 5 -exotet cyclization to give furan core $\mathbf{8}$. Two orthogonal protections of the alcohol moieties and selective deprotection then gave compound 4 (Scheme 2).

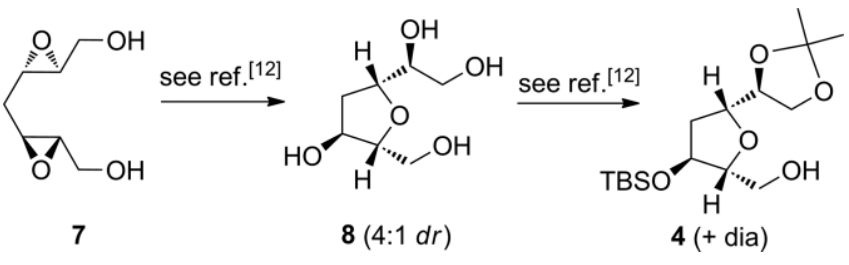

Scheme 2. Synthesis of intermediate 4.

Primary alcohol 4 was transformed into the corresponding aldehyde with Dess-Marin periodinane (DMP) (Scheme 3). Onecarbon homologation through a Wittig reaction using commercially available methyltriphenylphosphonium bromide introduced the first side-chain in $77 \%$ overall yield. Reduction of the terminal double bond by catalytic hydrogenation $(\mathrm{Pd} / \mathrm{C})$ gave intermediate 9 in $91 \%$ yield. Before the second side-chain was introduced, the primary alcohol was selectively deprotected by Rychnovsky's method ${ }^{[20]}$ by converting the 1,2-diol acetonide into a secondary 1-methylcyclopropyl ether. By treatment with TMSOTf and $i \mathrm{Pr}_{2} \mathrm{NEt}$, acetal 9 was cleaved to give an enol ether, which was then directly stabilized by Simmons-Smith cyclopropanation. TMS cleavage under basic conditions then gave 1methyl-1-cyclopropyl hydroxy derivative $\mathbf{1 0}$ in $\mathbf{4 8} \%$ yield over three steps. Thankfully, the minor diastereoisomer of $\mathbf{1 0}$ (arising from the Payne reaction) was eliminated at this stage by simple flash chromatography. Finally, the second side-chain was introduced through DMP oxidation of primary alcohol $\mathbf{1 0}$ followed by Horner-Wadsworth-Emmons olefination with the previously described $\beta$-ketophosphonate $\mathbf{1 1}^{[21]}$ in the presence of $\mathrm{Ba}(\mathrm{OH})_{2} \cdot{ }^{[22]}$ This gave enone 12 in $87 \%$ yield over two steps. It is important to note that the oxidation step needed to be carried out in degassed $\mathrm{CH}_{2} \mathrm{Cl}_{2} \cdot{ }^{[23]}$ Selective deprotection of the cyclopropyl group of $\mathbf{1 2}$ was achieved by mild oxidation with $\mathrm{N}$-bromosuccimide to give compound $\mathbf{1 3}$ in $79 \%$ yield. ${ }^{[20]}$
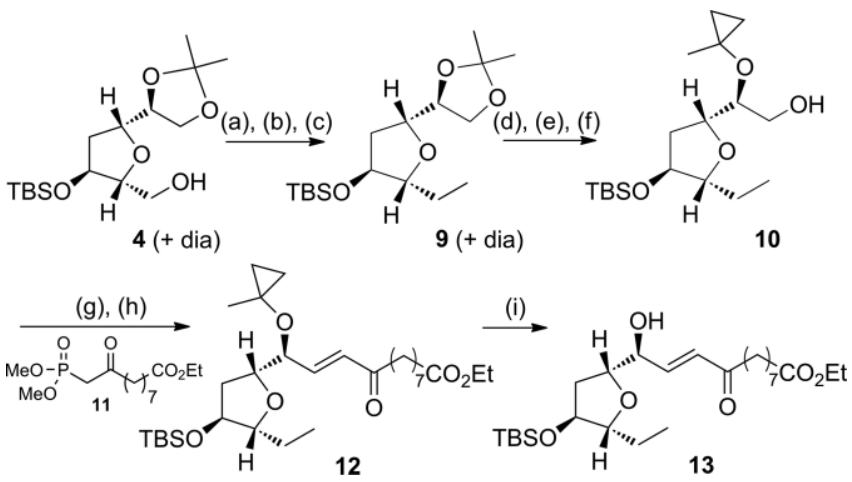

Scheme 3. (a) DMP, $\mathrm{NaHCO}_{3}, \mathrm{CH}_{2} \mathrm{Cl}_{2} / \mathrm{H}_{2} \mathrm{O}, 0^{\circ} \mathrm{C}$ to r.t.; (b) $\mathrm{BrPh}_{3} \mathrm{PCH}_{3}, \mathrm{NaHMDS}$, THF, $-78{ }^{\circ} \mathrm{C}$ to r.t., $79 \%$ over two steps; (c) $\mathrm{H}_{2}, \mathrm{Pd} / \mathrm{C}, \mathrm{MeOH}$, r.t., $91 \%$; (d) iPrNEt, TMSOTf, $\mathrm{CH}_{2} \mathrm{Cl}_{2}, 0{ }^{\circ} \mathrm{C}$ to r.t., then reflux; (e) $\mathrm{Et}_{2} \mathrm{Zn}_{1} \mathrm{CH}_{2} \mathrm{I}_{2}$, $\mathrm{Et}_{2} \mathrm{O}$, r.t.; (f) $\mathrm{K}_{2} \mathrm{CO}_{3}, \mathrm{MeOH}$, r.t., $48 \%$ over three steps; (g) DMP, $\mathrm{CH}_{2} \mathrm{Cl}_{2}$ degassed, $0{ }^{\circ} \mathrm{C}$ to r.t.; (h) 9, $\mathrm{Ba}(\mathrm{OH})_{2}, \mathrm{THF} / \mathrm{H}_{2} \mathrm{O}, 87 \%$ over two steps; (i) $\mathrm{NBS}, \mathrm{THF} / \mathrm{H}_{2} \mathrm{O}$, r.t., $79 \%$. TMS: trimethylsilyl; Tf: trifluoromethylsulfonyl; NBS: $N$-bromosuccinimide; DMP: Dess-Martin periodinane; NaHMDS: sodium bis(trimethylsilyl)amide.

At this stage, Luche reduction of enone $\mathbf{1 3}$ gave access to allylic alcohol epimers (S)-14 and (R)-14 as a 1:1 mixture in $90 \%$ yield, called (RS)-14 (Scheme 4). The TBS group was removed using tetrabutylammonium fluoride, and then ester saponification in the presence of lithium hydroxide gave enediol ent-9(RS)-12-epi-ST- $\Delta^{10}-13-P h y t o F(R S)-2$ in $94 \%$ yield. We also synthesized both ( $9 R$ ) and (9S) epimers of ent-9(RS)-12-epi-ST- $\Delta^{10}$ 13-PhytoF (2), using Corey-Bakshi-Shibata oxazaborolidines for the stereoselective reduction of enone 13. As a result, $(9 S)$ derivative (S)-14 and (9R) derivative ( $R$ )-14 were obtained in 89 and $76 \%$ yields, respectively, with a good diastereoisomeric ratio ( $d r$ 9:1) in both cases. Finally, the TBS cleavage/saponification sequence gave ent-9-(S)-12-epi-ST- $\Delta^{10}$-13-PhytoF (S)-2 and (R)-2

$$
\begin{array}{ll}
\text { (a) or (b) } & (S)-2: \mathrm{R}^{1}=\mathrm{H} ; \mathrm{R}^{2}=\mathrm{OH} \\
\text { (S)-14: } \mathrm{R}^{1}=\mathrm{H} ; \mathrm{R}^{2}=\mathrm{OH} & \begin{array}{l}
\text { ent-9(S)-12-epi-ST- } \Delta^{10}-13-\text { PhytoF } \\
(R)-14: \mathrm{R}^{1}=\mathrm{OH} ; \mathrm{R}^{2}=\mathrm{H}
\end{array} \\
\text { ent-9(R)-12-epi-ST- } \mathrm{R}^{1}=\mathrm{OH} \mathrm{R}^{2}=\mathrm{H} \\
\text { ent-PhytoF }
\end{array}
$$

Scheme 4. (a) $\mathrm{CeCl}_{3} \cdot 7 \mathrm{H}_{2} \mathrm{O}, \mathrm{NaBH}_{4}, \mathrm{MeOH}, 0{ }^{\circ} \mathrm{C}$ to r.t., $90 \%$ for (RS)-14, $d r$ 1:1; (b) (R)-methyl-CBS-oxazaborolidine, $\mathrm{BH}_{3} \cdot \mathrm{Me}_{2} \mathrm{~S}$, $\mathrm{THF}, 0{ }^{\circ} \mathrm{C}$ to r.t., $89 \%$ for $(S)$ 14, dr: 9:1; (c) (S)-methyl-CBS-oxazaborolidine, $\mathrm{BH}_{3} \cdot \mathrm{Me}_{2} \mathrm{~S}, \mathrm{THF}, 0{ }^{\circ} \mathrm{C}$ to r.t., $76 \%$ for (R)-14, dr: 9:1; (d) TBAF, THF, r.t.; (e) $\mathrm{LiOH}, \mathrm{THF} / \mathrm{H}_{2} \mathrm{O}$, r.t.; $94 \%$ for $(R S)-\mathbf{2}$; $67 \%$ for (S)-2; $90 \%$ for (R)-2 over two steps. CBS: Corey-Bakshi-Shibata; TBAF: tetrabutylammonium fluoride. 
in 64 and $90 \%$ yields, respectively. Thus, we achieved the total synthesis of ent-9-(RS)-12-epi-ST- $\Delta^{10}$-13-PhytoF (RS)-2 (24 mg), of the (9S) epimer (S)-2 (13 mg), and of the (9R) epimer $(R)-\mathbf{2}$ (15 mg) in 20,14, and $16 \%$ yields, respectively, in 12 steps starting from monoprotected TBS ether 4.

The synthesis of enediol-PhytoF $\mathbf{2}$ confirmed that our core structure 4 could be used to obtain various enediol-PhytoFs. However, it remained to be seen whether our chosen orthogonal protecting groups could provide access to alkenyl PhytoFs. By switching the order of deprotection of the primary alcohols, the upper side-chain could be introduced first (Scheme 1). To illustrate the flexibility of our strategy, we then turned our attention to the synthesis of alkenyl ent-9(RS)-12-epi-ST- $\Delta^{10}-13$ PhytoF (3), as described below.

Starting from diprotected TBS acetal $\mathbf{6}^{[12]}$ the 1,2 -acetonide was transformed by Rychnovsky's three-step sequence into the 1-methyl-1-cyclopropyl hydroxy derivative $\mathbf{5}$ with a free primary alcohol in $80 \%$ yield (Scheme 5). The insertion of the upper side-chain ( $\alpha$-chain) was carried out after DMP oxidation by Wittig reaction using phosphonium salt $\mathbf{1 5}$ with NaHMDS as a base. The resulting (Z)-alkene 16, obtained in $40 \%$ yield over two steps, was then hydrogenated using palladium on charcoal to give the corresponding alkane in $91 \%$ yield. Regioselective deprotection of the primary alcohol was achieved using pyridinium para-toluenesulfonate in ethanol at $0{ }^{\circ} \mathrm{C}$. This nonoptimized step gave the free alcohol in $46 \%$ yield $(61 \%$ based on recovered starting material) without the undesired minor diastereoisomer, which was removed by flash chromatography.
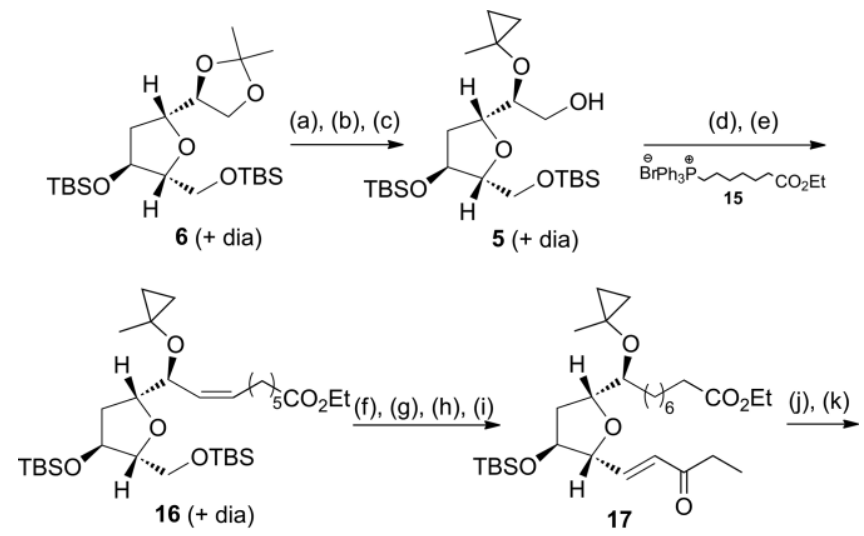

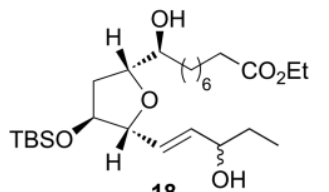

18

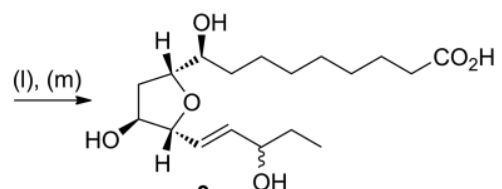

3
Scheme 5. (a) iPrNEt, TMSOTf, $\mathrm{CH}_{2} \mathrm{Cl}_{2}, 0{ }^{\circ} \mathrm{C}$ to room temp., then reflux; (b) $\mathrm{Et}_{2} \mathrm{Zn}, \mathrm{CH}_{2} \mathrm{I}_{2}, \mathrm{Et}_{2} \mathrm{O}$, r.t.; (c) $\mathrm{K}_{2} \mathrm{CO}_{3}, \mathrm{MeOH}$, r.t., 80 \% over three steps; (d) DMP, $\mathrm{CH}_{2} \mathrm{Cl}_{2}, 0{ }^{\circ} \mathrm{C}$ to r.t.; (e) $15, \mathrm{NaHMDS}$, THF, $-78{ }^{\circ} \mathrm{C}$ to r.t., $40 \%$ over two steps; (f) $\mathrm{H}_{2}, \mathrm{Pd} / \mathrm{C}, \mathrm{EtOH}$, r.t., $91 \%$; (g) PPTS, EtOH, $0{ }^{\circ} \mathrm{C}, 46 \%$ (61\% based on recovered starting material); (h) DMP, $\mathrm{NaHCO}_{3}, \mathrm{CH}_{2} \mathrm{Cl}_{2} / \mathrm{H}_{2} \mathrm{O}, 0{ }^{\circ} \mathrm{C}$ to r.t.; (i) diethyl (2-oxobutyl)phosphonate, $\mathrm{Ba}(\mathrm{OH})_{2}, \mathrm{THF} / \mathrm{H}_{2} \mathrm{O}, 20 \%$ over two steps; (j) NBS, THF/ $\mathrm{H}_{2} \mathrm{O}$, r.t., $83 \%$; (k) $\mathrm{CeCl}_{3} \cdot 7 \mathrm{H}_{2} \mathrm{O}, \mathrm{NaBH}_{4}, \mathrm{MeOH}, 0{ }^{\circ} \mathrm{C}$ to r.t., $77 \%$; (I) TBAF, THF, r.t., $74 \%$; $(\mathrm{m}) \mathrm{LiOH}, \mathrm{THF} / \mathrm{H}_{2} \mathrm{O}$, r.t., $72 \%$. PPTS: pyridinium para-toluenesulfonate.
Next, a tandem oxidation/HWE reaction with commercially available diethyl (2-oxobutyl)phosphonate gave the expected enone $\mathbf{1 7}$ in $20 \%$ yield. The methylcyclopropyl group was then removed in the presence of $\mathrm{N}$-bromosuccinimide, before reduction of the enone to give intermediate 18 in $64 \%$ yield. Deprotection of the silyl ether with TBAF and saponification of the ethyl ester with LiOH gave alkenyl ent-16(RS)-9-epi-ST- $\Delta^{14}-10$ PhytoF (3) in $53 \%$ yield (1.6 mg). Thus, the flexibility of our strategy was confirmed with this first synthesis of alkenylPhytoF ent-16(RS)-9-epi-ST- $\Delta^{14}-10-$ PhytoF (3), starting from diprotected TBS acetal 6, and achieved in 13 steps and $1.2 \%$ overall yield.

\section{Measurement of Phytofurans}

To date, phytofurans have not been identified in mammalian samples. In our previous report, ${ }^{[12]}$ the first compound synthesized, ent-16(RS)-13-epi-ST- $\Delta^{14}-9-P h y t o F(1)$, was found to be present in nuts and seeds (flax, chia, walnut, pine). Flax seed did not show the highest level of ent-16(RS)-13-epi-ST- $\Delta^{14}-9$ PhytoF (1), even though the level of the precursor, ALA, was higher than in chia, pine seeds, and walnut. For this reason, flax-seed oil (FSO) and flaxseed (FS) were chosen as the diet for this study. Here, we report the first quantitation of PhytoFs in the liver tissues of Sprague Dawley rats fed with FS and FSO.

As shown in Figure 1, substantial amounts of PhytoFs were present in the liver of the control rat, but only ent-16(RS)-13epi-ST- $\Delta^{14}$-9-PhytoF (1) and ent-16(RS)-9-epi-ST- $\Delta^{14}-10-P h y t o F$ (3) were detectable; the concentration of PhytoF $\mathbf{3}$ was higher than that of PhytoF 1 (2.5:1 ratio). Other PhytoFs (R)-2 and (S)$\mathbf{2}$ were not measureable in the same liver samples. The absence of the latter compounds is probably due to a low abundance, below the detection limit of LC-MS/MS. ${ }^{[19]}$ Regardless of this limitation, we showed that the concentrations of PhytoF 1 and PhytoF $\mathbf{3}$ were not elevated in the liver after $28 \mathrm{~d}$ of the FSO and FS diets compared to the control. In fact, a lower PhytoF 1 concentration ( $p=0.009$ ) was found for the FSO group. The concentration ratio of $\mathbf{1 / 3}$ was elevated after the FSO diet (1:6.6) compared to the FS diet (1:1.3).

We anticipated that an increase in ALA in the diet would elevate the levels of PhytoFs. Interestingly, the ALA level was not significantly increased by the FSO and FS diets compared to the control. ${ }^{[24]}$ In fact, we observed a noticeable negative correlation ( $p=0.023$ ) between the ALA concentration and the total concentration of PhytoFs (PhytoF 1 plus PhytoF 3) of the FSO group only. ${ }^{[19]}$ This was largely due to the concentration of PhytoF 1 of the FSO group ( $p=0.026$ ). This result provides a further indication that the metabolism of this molecule is not ALA-dependent.

Nonetheless, the low liver PhytoF concentrations were foreseen, as the rodents were not under oxidative stress. The generation of PhytoFs in vivo occurs at high oxygen concentrations, or in the presence of excessive reactive oxygen species (ROS). In addition, the predisposed antioxidant capacity of FSO and FS may have contributed to the low levels of PhytoFs; extract of FSO showed a high antioxidant activity compared to other common nuts and seeds found in the human diet (data not shown). 

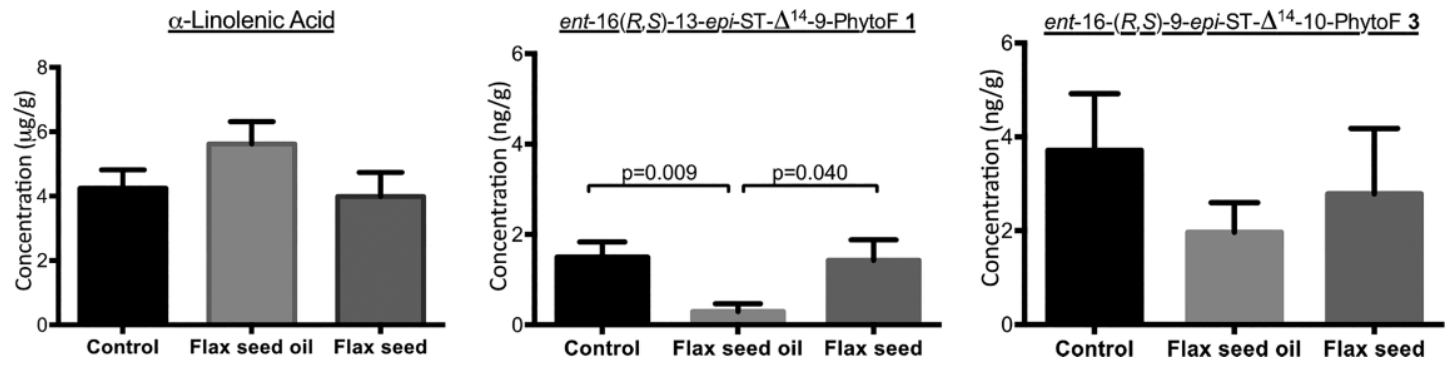

Figure 1. Concentration of $\alpha$-linolenic acid and phytofurans in the liver tissue of Sprague Dawley rats after supplementation. The values of each column are expressed as mean \pm SEM (standard error of mean), $n=6$.

Overall, we have demonstrated the presence of ent-16(RS)-13epi-ST- $\Delta^{14}-9$-PhytoF (1) and ent-16(RS)-9-epi-ST- $\Delta^{14}-10-$ PhytoF (3) in rat liver tissues, and shown that a high ALA level in the diet, without great oxidative stress, did not induce the generation of these PhytoFs.

\section{Conclusions}

We have described the synthesis of ent-9(RS)-12-epi-ST- $\Delta^{14}-13-$ PhytoF (RS)-2, as well as of both the individual epimers, $(R)-\mathbf{2}$ and (S)-2, and also of ent-16(RS)-9-epi-ST- $\Delta^{14}-10$-PhytoF (3). The total syntheses were achieved through a flexible and convergent strategy that gives access to the enediol and alkenyl types of PhytoFs for the first time. This strategy may be useful to complete the synthesis of other polyunsaturated fatty acid metabolites (isofurans, neurofurans, and dihomo-isofurans). With these new metabolites in hand, we also highlighted the presence of ent-16(RS)-13-epi-ST- $\Delta^{14}$-9-PhytoF (1) and ent-16(RS)-9epi-ST- $\Delta^{14}$-10-PhytoF (3) in mammalian liver. These metabolites are currently undergoing testing as oxidative stress biomarkers in disease models. Their potential roles as biologically active compounds in pathogenesis are also under investigation.

\section{Experimental Section}

General Remarks: Experimental data, procedures, and NMR spectra are found in the Supporting Information, along with details of the rodent feeding and analysis of the liver samples for ALA and PhytoFs.

\section{Typical Procedure for the Acetonide Deprotection}

(S)-2-\{(2R,4S,5R)-4-[(tert-Butyldimethylsilyl)oxy]-5-ethyltetrahydrofuran-2-yl\}-2-(1-methylcyclopropoxy)ethanol (10): Acetonide 9 (168 mg, $0.509 \mathrm{mmol}, 1$ equiv.) was dissolved in $\mathrm{CH}_{2} \mathrm{Cl}_{2}(5 \mathrm{~mL})$, and freshly distilled $i \operatorname{Pr}_{2} \mathrm{NEt}(173 \mu \mathrm{L}, 1.18 \mathrm{mmol}, 1$ equiv.) was added. The mixture was cooled to $0{ }^{\circ} \mathrm{C}$, and then freshly distilled TMSOTf (157 $\mu \mathrm{L}, 0.87 \mathrm{mmol}, 1.7$ equiv.) was added dropwise. The mixture was warmed to room temp. and then heated at reflux overnight. Then, the mixture was diluted with hexane and filtered through a plug of neutral alumina (activity III; $6 \%$ of water), which was then rinsed with hexane/EtOAc (9:1). The filtrate was concentrated under reduced pressure. The resulting enol ether was dissolved in $\mathrm{Et}_{2} \mathrm{O}$ (5 mL). Then, $\mathrm{Et}_{2} \mathrm{Zn}$ ( $1 \mathrm{M}$ in decane; $1.53 \mathrm{~mL}, 1.53 \mathrm{mmol}, 3$ equiv.) was added prior to distilled $\mathrm{CH}_{2} \mathrm{I}_{2}(222 \mu \mathrm{L}, 2.55 \mathrm{mmol}, 5$ equiv.), which was added over $10 \mathrm{~min}$. The mixture was stirred at room temp. overnight. The reaction mixture was diluted with $\mathrm{NaOH}(1 \mathrm{~N}$ aq.; $10 \mathrm{~mL})$, and the mixture was extracted with $\mathrm{Et}_{2} \mathrm{O}(3 \times 7 \mathrm{~mL})$.
The combined organic extracts were dried with $\mathrm{MgSO}_{4}$ and concentrated under reduced pressure. The resulting crude oil was treated with $\mathrm{K}_{2} \mathrm{CO}_{3}(19 \mathrm{mg})$ in $\mathrm{MeOH}(5 \mathrm{~mL})$ at room temp. for $15 \mathrm{~min}$ to remove the remaining TMS group. The mixture was then quenched with saturated $\mathrm{NH}_{4} \mathrm{Cl}$ and extracted with $\mathrm{Et}_{2} \mathrm{O}(3 \times 4 \mathrm{~mL})$. The combined organic extracts were dried with $\mathrm{MgSO}_{4}$ and concentrated under reduced pressure. Purification by flash chromatography (silica gel was treated with $2 \% \mathrm{Et}_{3} \mathrm{~N}$ before elution with pentane/EtOAc, 9:1) gave 1-methyl-1-cyclopropyl (MCP) hydroxy derivative $\mathbf{1 0}$ (84 mg, $48 \%$ ), free from its diastereoisomer, as a colorless oil. $R_{\mathrm{f}}=$ 0.43 (cyclohexane/EtOAc, 7:3). $[\alpha]_{\mathrm{D}}^{20}=+35.8\left(c=1 \times 10^{-2}, \mathrm{CHCl}_{3}\right)$. ${ }^{1} \mathrm{H}$ NMR $\left(500 \mathrm{MHz}, \mathrm{CDCl}_{3}\right): \delta=4.13-4.06(\mathrm{~m}, 1 \mathrm{H}, \mathrm{CH}), 3.95-3.90(\mathrm{~m}$, $1 \mathrm{H}, \mathrm{CH}), 3.74-3.66\left(\mathrm{~m}, 2 \mathrm{H}, \mathrm{CH}_{2}\right), 3.62-3.56(\mathrm{~m}, 2 \mathrm{H}, \mathrm{CH}), 2.47$ (br., $1 \mathrm{H}, \mathrm{OH}), 1.85-1.80\left(\mathrm{~m}, 2 \mathrm{H}, \mathrm{CH}_{2}\right), 1.55-1.34(\mathrm{~m}, 5 \mathrm{H}$, including $\mathrm{m}, 2$ $\mathrm{H}, \mathrm{CH}_{2}$ and $\left.\mathrm{s}, 3 \mathrm{H}, \mathrm{CH}_{3}\right), 0.94\left(t, J=7.5 \mathrm{~Hz}, 3 \mathrm{H}, \mathrm{CH}_{3}\right), 0.89-0.84(\mathrm{~m}$, $11 \mathrm{H}$, including $\mathrm{s}, 9 \mathrm{H}, \mathrm{CH}_{3}$ and $\left.\mathrm{m}, 2 \mathrm{H}, \mathrm{CH}_{2}\right), 0.45-0.37(\mathrm{~m}, 2 \mathrm{H}$, $\left.\mathrm{CH}_{2}\right), 0.07-0.01\left(\mathrm{~m}, 6 \mathrm{H}, \mathrm{CH}_{3}\right)$ ppm. ${ }^{13} \mathrm{C} \mathrm{NMR}\left(125 \mathrm{MHz}, \mathrm{CDCl}_{3}\right): \delta=$ $88.3(1 \mathrm{C}, \mathrm{CH}), 79.5(1 \mathrm{C}, \mathrm{CH}), 78.6(1 \mathrm{C}, \mathrm{CH}), 75.9(1 \mathrm{C}, \mathrm{CH}), 63.8(1$ $\left.\mathrm{C}, \mathrm{CH}_{2}\right), 58.4\left(1 \mathrm{C}, \mathrm{C}_{\mathrm{q}}\right), 38.2\left(1 \mathrm{C}^{\mathrm{C}} \mathrm{CH}_{2}\right), 27.0\left(1 \mathrm{C}, \mathrm{CH}_{2}\right), 25.9(3 \mathrm{C}$, $\left.\mathrm{CH}_{3}\right), 22.7\left(1 \mathrm{C}_{2} \mathrm{CH}_{3}\right), 18.1\left(1 \mathrm{C}, \mathrm{C}_{\mathrm{q}}\right), 14.5\left(1 \mathrm{C}_{\mathrm{C}} \mathrm{CH}_{2}\right), 13.5\left(1 \mathrm{C}, \mathrm{CH}_{2}\right)$, $10.6\left(1 \mathrm{C}, \mathrm{CH}_{3}\right),-4.4\left(1 \mathrm{C}_{,} \mathrm{CH}_{3}\right),-4.6\left(1 \mathrm{C}_{1} \mathrm{CH}_{3}\right)$ ppm. IR: $\tilde{v}=3448$, 2957, 2858, 1463, 1384, 1254, 1110, 1044, 935, 833, $774 \mathrm{~cm}^{-1}$. MS $\left(\mathrm{ES}^{+}\right): \mathrm{m} / z=367.23[\mathrm{M}+\mathrm{Na}]^{+}$. HRMS $\left(\mathrm{ESI}^{+}\right)$: calcd. for $\mathrm{C}_{18} \mathrm{H}_{36} \mathrm{O}_{4} \mathrm{SiNa}$ $[\mathrm{M}+\mathrm{Na}]^{+}$367.2281; found 367.2280 .

\section{Acknowledgments}

We thank the University of Montpellier (UM) for a doctoral fellowship for C. C., and the drug cabinet of the Faculty of Pharmacy of Montpellier for the graphical abstract pictures. This work was carried out, in partnership with the SAS PIVERT, within the framework of the French Institute for Energy Transition [Institut pour la Transition Energétique (ITE) PIVERT] (www.institutpivert.com), selected as an Investment for the Future ("Investissements d'Avenir"). This work was supported, as part of the Investments for the Future, by the French Government under the reference ANR-001-01, and by the Centre National de la Recherche Scientifique (CNRS) under the reference INC-PICS261141-EvaPhytoFood.

\section{Keywords: Total synthesis · Oxidative stress · Fatty acids} Phytofurans · Biomarkers

[1] J. D. Morrow, K. E. Hill, R. F. Burk, T. M. Nammour, K. F. Badr, L. Roberts, Proc. Natl. Acad. Sci. USA 1990, 87, 9383-9387.

[2] M. VanRollins, R. L. Woltjer, H. Yin, J. D. Morrow, T. J. Montine, J. Lipid Res. 2008, 49, 995-1005. 
[3] J. Nourooz-Zadeh, E. H. C. Liu, B. Yhlen, E. E. Änggåard, B. Halliwell, J. Neurochem. 1999, 72, 734-740.

[4] a) U. Jahn, J.-M. Galano, T. Durand, Angew. Chem. Int. Ed. 2008, 47, 58945955; Angew. Chem. 2008, 120, 5978; b) J.-M. Galano, J. C.-Y. Lee, C. Gladine, B. Comte, J.-Y. Le Guennec, C. Oger, T. Durand, Biochim. Biophys. Acta 2015, 1851, 446-455.

[5] J. Roy, C. Oger, J. Thireau, J. Roussel, O. Mercier-Touzet, D. Faure, E. Pinot, C. Farah, D. F. Taber, J.-P. Cristol, C. Y. L. Lee, A. Lacampagne, J.-M. Galano, T. Durand, J.-Y. Le Guennec, Free Radical Biol. Med. 2015, 86, 269-278.

[6] S. Parchmann, M. J. Mueller, J. Biol. Chem. 1998, 273, 32650-32655.

[7] R. Imbusch, M. Mueller, J. Free Radical Biol. Med. 2000, 124, 1293.

[8] L. Minghetti, R. Salvi, M. L. Salvatori, M. A. Ajmone-Cat, C. De Nuccio, S. Visentin, V. Bultel-Poncé, C. Oger, A. Guy, J.-M. Galano, A. Greco, A. Bernardo, T. Durand, Free Radical Biol. Med. 2014, 73, 41-50.

[9] J. P. Fessel, N. A. Porter, K. P. Moore, J. R. Sheller, L. J. Roberts II, Proc. Natl. Acad. Sci. USA 2002, 99, 16713-16718.

[10] A. de la Torre, Y. Y. Lee, C. Oger, P. T. Sangild, T. Durand, J. C. Y. Lee, J.-M. Galano, Angew. Chem. Int. Ed. 2014, 53, 6249-6252; Angew. Chem. 2014, 126, 6363-6366.

[11] W.-L. Song, J. A. Lawson, D. Reilly, J. Rokach, C.-T. Chang, B. Giasson, G. A. FitzGerald, J. Biol. Chem. 2008, 283, 6-16.

[12] C. Cuyamendous, K. S. Leung, T. Durand, J. C.-Y. Lee, C. Oger, J.-M. Galano, Chem. Commun. 2015, 51, 15696-15699.

[13] For a recent review on furanic metabolites of polyunsaturated fatty acids, see: C. Cuyamendous, A. de la Torre, Y. Y. Lee, K. S. Leung, A. Guy, V.
Bultel-Poncé, J.-M. Galano, C. Oger, T. Durand, Biochimie 2016, 130, 49 62.

[14] For the nomenclature of isofuranic compounds, see: a) D. J. Taber, L. J. Roberts II, Prostaglandins Other Lipid Mediators 2004, 73, 47-50; b) D. J. Taber, L. J. Roberts II, Prostaglandins Other Lipid Mediators 2005, 78, 14 18.

[15] a) D. J. Taber, Y. Pan, X. Zhao, J. Org. Chem. 2004, 69, 7234-7240; b) D. J. Taber, P. Gu, R. Li, J. Org. Chem. 2009, 74, 5516-5522.

[16] D. J. Taber, Z. Zhang, J. Org. Chem. 2006, 71, 926-933.

[17] M. Valli, P. Bruno, D. Sbarbada, A. Porta, G. Vidari, G. Zanoni, J. Org. Chem. 2013, 78, 5556-5567.

[18] A. de la Torre, Y. Y. Lee, A. Mazzoni, A. Guy, V. Bultel-Poncé, T. Durand, C. Oger, J. C.-Y. Lee, J.-M. Galano, Chem. Eur. J. 2015, 21, 2442-2446.

[19] See the Supporting Information.

[20] S. D. Rychnovsky, J. Kim, Tetrahedron Lett. 1991, 32, 7219-7222.

[21] S. El Fangour, A. Guy, V. Despres, J.-P. Vidal, J.-C. Rossi, T. Durand, J. Org. Chem. 2004, 69, 2498-2503.

[22] I. Paterson, K.-S. Yeung, J. B. Smaill, Synlett 1993, 774-776.

[23] For the syntheses of PhytoFs 1, 2, and 3, several oxidations using DessMartin periodinane were carried out. These proceeded differently from one substrate to another (dry $\mathrm{CH}_{2} \mathrm{Cl}_{2}$ or not, and/or degassed $\mathrm{CH}_{2} \mathrm{Cl}_{2}$ or not).

[24] R. A. Gibson, M. A. Neumann, E. L. Lien, K. A. Boyd, W. C. Tu, Prostaglandins, Leukotrienes Essent. Fatty Acids 2013, 88, 139-146. 